\title{
An Introduction of Islamic Value-Based Productivity Framework
}

\author{
Nurul Ain Mohammad Rosli ${ }^{1 *}$, Norazilawati Md Dahlal ${ }^{2}$, Amal A.M. Elgharbawy ${ }^{3}$ \\ ${ }^{1}$ M.A Student in International Institute for Halal Research and Training (INHART), International Islamic \\ University Malaysia, P.O. Box 10, 50278 Kuala Lumpur, Malaysia \\ ${ }^{2}$ Lecturer and Assistant Professor in International Institute for Halal Research and Training (INHART), \\ International Islamic University Malaysia, P.O. Box 10, 50278 Kuala Lumpur, Malaysia \\ ${ }^{3}$ Lecturer and Assistant Professor in International Institute for Halal Research and Training (INHART), \\ International Islamic University Malaysia, P.O. Box 10, 50278 Kuala Lumpur, Malaysia
}

\begin{abstract}
*Corresponding Authors: Nurul Ain Mohammad Rosli, M.A Student in International Institute for Halal Research and Training (INHART), International Islamic University Malaysia, P.O. Box 10, 50278 Kuala Lumpur, Malaysia
\end{abstract}

\begin{abstract}
Productivity is commonly used in measuring the efficiency of production. Both conventional and Islamic perspectives come with the same general meaning of productivity and the importance of the values also take place in both perspectives. The values of the conventional productivity concept measured by using tangible indicators such as skills and knowledge of workers. While in the Islamic perspective, the values of productivity are measured beyond the tangible indicators; and show that it is holistic and comprehensive. Even though the interest in values is expanding, the discussion only continues conceptually, narrowly focusing on the list of Islamic values. In addition, no empirical evidence has been recorded as far as the researchers are concerned, which scientifically explains the application of Islamic values, specifically in productivity. Therefore, this study aims to introduce an Islamic value-based productivity framework from the identification and interpretation of selected Quranic verses related to productivity. By applying a descriptive research design, this study has used the content analysis method. The findings showed that the Islamic valuebased productivity framework consists of four main indicators; faith, intention, time: as inputs, and job satisfaction as outputs. The values extracted from these indicators consist of eight values which are Ihsan (Excellence), Itqan, Taqwa, Shukr (Gratitude), Istiqamah, Sabr (Patience), Tawakkul and Barakah (Divine Blessing).
\end{abstract}

Keywords: Productivity, Values, Islamic Values, Value-based Productivity

\section{INTRODUCTION}

Generally, productivity is defined as the ratio between total output and total input. In industry, productivity has been used in measuring the efficiency of production, which consists of manpower and capital to ensure optimal production output. The concept is constant energy that will motivate an individual to take practical steps to achieve a goal. This will create a concept of 'industrialization' to develop the country's capacity to produce secondary goods and services. However, the question arises is whether this concept is suitable to be practiced in Islamic institutions and operated by Muslims? This is because both conventional and Islamic perspectives come with the same general meaning of productivity, and the importance of the values also occur in conventional perspective. The values of the conventional productivity concept are measured by using tangible indicators such as skills and knowledge of workers. From the Islamic perspective, the values of productivity are measured beyond the tangible indicators; and show that it is holistic and comprehensive.

Productivity is a measure of the efficiency of a person completing a task. It is not how many tasks the person can complete in a certain period, but getting the important tasks completed consistently. The current practice of productivity from a conventional perspective mainly focuses on effectiveness and the quantity of production. Simply put, how much output is obtained from a given set of input (Syverson, 2011). The general concept is similar to Islamic Value-based Productivity; the difference is that only the Islamic Value-based Productivity emphasizes the importance of Islamic Values in productivity. How can Islamic Values improve and sustain the productivity of a person? Therefore, 
contemporary studies have conceptualized the relation of Islamic values to organizational effectiveness (Hayati Ishak et. al., 2018; Ishak et.al., 2015).

Consequently, this article aims to introduce an Islamic value-based productivity framework from the identification and interpretation of selected Quranic verses related to productivity. The introduction of the concept of Islamic value-based productivity was expected to be used in an Islamic institution. This study covers three objectives using exploratory and descriptive methods and content analysis methods. Firstly, to identify the verses of the Quran that are related to productivity. Second, to analyse and extract the element of Islamic values on the selected verses using content analysis. Finally, this study has concluded the Islamic value-based productivity framework.

\section{LITERATURE REVIEW}

\subsection{The Concept of Productivity}

The general concept of productivity is the ability to produce a certain amount of output from the set of given inputs (Syverson, 2011). Economically, productivity describes how an economy uses existing resources optimally through the measurement of output associated with inputs. The output of the productivity is indirectly representing the efficiency and the effectiveness of the resources used such as the technology and labor force (Gordon $J$ et al., 2015). Inputs or the main resources in producing productivity are, for example, workers and the working hours. Meanwhile, the output refers to the quantity of products delivered, for example, in Malaysia, the productivity will be measured and recorded through Malaysia Productivity Report (MPR) which includes labor productivity growth and Gross Domestic Product (GDP).

According to the (Malaysia Productivity Report, 2019) productivity is the relationship between the amount of output produced and the amount of input used to produce the output. Higher productivity means achieving more with the same or lesser amount of input resources. An increase in productivity will lead to a higher standard of living, enhanced competitiveness, and a better quality of life.

Malaysia's economic development and growth are determined by improvements in our jobs and growth in labor productivity. Growth in labor productivity implies that more value is added to products and services to generate more distribution revenue. Growth in labor productivity is influenced by various factors involving growth in multi-factor productivity (MFP) and capital intensity. First, multi-factor productivity is a measure of efficiency in the utilization of inputs when the better-quality inputs result in the greater output especially when inputs are utilized effectively and efficiently. Second, capital intensity refers to the utilization of capital within the workforce (Malaysia Productivity Report, 2019).

In addition, the conventional labor productivity indicators specifically in Malaysia used these three indicators in measuring productivity. The most frequently used is the added values per employee indicator.

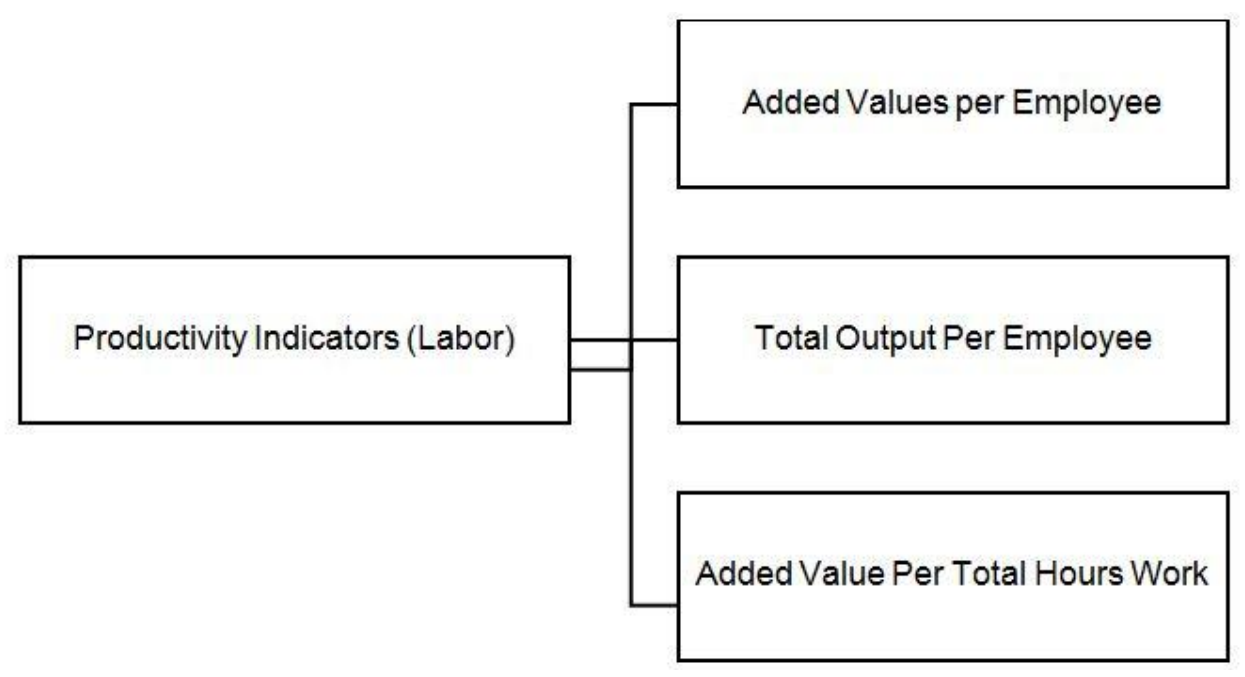

Figure1. The Indicators of Productivity for Labour

Source: $26^{\text {th }}$ Malaysia Productivity Report (2019) 


\subsection{Islamic Productivity}

Islamic productivity is closely related to the concept of work. In Islam, working is very important, and it is compulsory for a Muslim to work and find a source of income. A previous study shows that, in Islam, work does not simply refer to earning a living for oneself and one's family by continually spending time, day and night, but it involves all types of practices or occupations that have elements of goodness and blessings for oneself, family and the surrounding community as well as the country (Hasmy, 2019).

According to (Hasmy, 2019), productivity in terminology is very closely related to work. Consequently, it can be concluded that productivity in Islam, especially what is discussed in the Qur'an is a very crucial concept. The verse in al-Quran discusses productivity as follows.

"Those who stay at home except those with valid excuses are not equal to those who strive in the cause of Allah with their wealth and their lives. Allah has elevated in rank those who strive with their wealth and their lives above those who stay behind 'with valid excuses?. Allah has promised each a fine reward, but those who strive will receive a far better reward than others." (An-Nisa', 4:95)

The keyword linked to efficiency in the above verse is the word "jihad". The verse, however, needs to be conceptually interpreted rather than contextually. The word "jihad" in the verse appears to be similar to the word "war" if we interpret the verse contextually, or in other words, jihad means physical warfare. If we interpret the verse conceptually, it would be different because there would be a broader meaning of the word 'jihad' in the verse. Conceptually, the word "jihad" in the verse can be interpreted as "working".

Meanwhile, based on Mohammed Faris (2017), the author highlighted the missing soul of productivity, which refers to the element of Barakah. What if we can control the uncontrollable, and how can we attract the hidden element to our success? According to Sheikh Imam Raghib Al-Isfahani, "the definition of Barakah is the attachment of Divine goodness to a thing, so if it occurs in something little, it increases it, and if it occurs in something abundant it further increases the benefit'. The author also emphasized that the definition of modern productivity is maximizing your output while the Barakah of productivity is maximizing the impact of the output, beyond expectation. The formula that has been concluded by the author in productivity is $\beta$ Energy $x \beta$ Focus $\times \beta$ Time $=\beta^{3}$ Outcome. $\beta$ refers to the element of Barakah.

\subsection{Definition of Islamic Values}

The word value is derived from Latin, 'valêre' that means to be strong or worthy. From the conceptual point of view, value refers to principles or standards of behavior. According to Henderson and Thompson (2003), value means a man's acts to satisfy his wants. Anything which satisfies a human need, thereby becomes a value. Our conduct is said to be motivated by our value is another way of saying that we act to satisfy our needs. Generally, values act as a measure that helps individuals identify their position in a social or moral issue. It is a guide to resolving conflicts, making decisions, and limiting one's behavior. Whereas Gellerman et. al (1990) have pointed out that value is a standard of importance based on beliefs. Once embraced, values play a significant role in personality and organizational culture, serving as criteria for making decisions and setting priorities.

According to Hayati Ishak et.al. (2018), Islamic values apply to a collection of good values foundin Quranic verses and prophetic traditions. Studies refer to the elaboration made by contemporary scholars as the revelations do not imply the principles explicitly. Additionally, based on Ali and Weir (2005), scholars who have discussed Islamic values proved that a wide variety of moral and beneficial principles have been emphasized in the Quran and the Prophetic tradition (Hadith and sunnah). Also, Islam emphasizes theological elements and moral injunctions in relation to behavior, unlike other religions. For instance, in the Islamic quality management context, as highlighted by Ishak et al. (2015), the elaboration of Islamic perspective in quality management is primarily related to a number of values endorsed by the primary source of Islamic teachings of the Quran and the prophetic tradition.

\section{RESEARCH METHODOLOGY}

This study is qualitative in nature and analysed via the content analysis method. The data has been collected from the primary Islamic source, al-Quran, and the discussion has been supported by using 
the tafsirIbnuKatheer and related hadith. Moreover, this study has also used secondary sources by using library search. The sources are related to previous studies and literature relevant to this study, such as theses, journals, websites, and literary works related to Islamic values, productivity, and Islamic productivity.

The study has been conducted in two parts. First, the Quranic verses related to productivity have been identified. The value of productivity in the selected verses has been extracted and classified as Islamic value-based productivity. Secondly, the findings have been discussed to understand the relationship between indicators of productivity and values of productivity. Finally, this study has concluded the Islamic value-based productivity framework.

\section{FINDINGS AND DISCUSSION}

By applying an exploratory and descriptive design using the content analysis method, the selected Quranic verses are analyzed and categorized by themes. The discussion in this section relates the tafsir's analysis of the selected Quranic verses to find Islamic values. Tafsirused in this study refers to TafsirIbnu Katheer.

The study shows thatthere are 43 verses of the Quran related to productivity asshown in Table 1 . Based on the classification, the study found sevenindicators involved in each input and output of the process of Islamic productivity. The indicators for the input are faith, intention and times, while for the output, the indicators are spiritual, social, intellectual and material. From these four indicators, the study found at least eight values that should be involved in the process of Islamic productivity.

Table1. The list of Quranic verses related to productivity

\begin{tabular}{|c|c|c|c|c|c|c|c|c|c|}
\hline \multirow[b]{2}{*}{ No } & \multirow[b]{2}{*}{ Verses Indicators } & \multicolumn{3}{|c|}{ INPUT } & \multicolumn{4}{|c|}{ OUTPUT } & \multirow[b]{2}{*}{ Identification of Value } \\
\hline & & 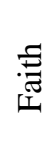 & 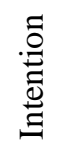 & $\stackrel{\mathscr{\Xi}}{\Xi}^{\mathscr{E}}$ & 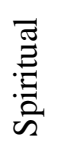 & $\begin{array}{l}\overline{\frac{\pi}{0}} \\
\overline{8} \\
\text { in }\end{array}$ & 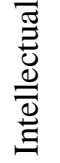 & 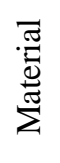 & \\
\hline 1 & Al-Baqarah (2:25) & 1 & & & 1 & & & & Taqwa, Ihsan \\
\hline 2 & Al-Baqarah (2:62) & I & & & I & & & & Taqwa, Ihsan \\
\hline 3 & Al-Baqarah (2:225) & & 1 & & 1 & & & & Taqwa \\
\hline 4 & Al-Imran (3:159-160) & 1 & & & 1 & 1 & & & Tawakkul \\
\hline 5 & Al-Imran (3:173-174) & 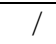 & & & 1 & & & & Tawakkul \\
\hline 6 & Al-Imran (3:179) & I & & & 1 & & & & Taqwa \\
\hline 7 & Al-Imran (3:190) & & & 1 & 1 & & & & Taqwa \\
\hline 8 & An-Nisa'(4:95) & 1 & & & 1 & & & 1 & Taqwa, Ihsan \\
\hline 9 & An-Nisa (4:103) & I & & & 1 & & & & Taqwa, Itqan \\
\hline 10 & An-Nisa $(4: 125)$ & I & & & 1 & & & & Taqwa, Itqan, Ihsan \\
\hline 11 & Al-Maidah (5:2) & 1 & & & 1 & 1 & & & Taqwa, Itqan \\
\hline 12 & Al-Araf (7:96) & 1 & & & 1 & & & & Taqwa, Barakah \\
\hline 13 & Al-Anfal (8:2-4) & 1 & & & 1 & & & & Taqwa, Ihsan,Tawakkul \\
\hline 14 & At-Taubah $(9: 105)$ & 1 & & & & & & & Taqwa \\
\hline 15 & Yunus (10:6) & & & 1 & 1 & & & & Taqwa \\
\hline 16 & Hud (11: 9-11) & 1 & & & 1 & & & & Sabr, Ihsan \\
\hline 17 & Hud (11:112) & 1 & & & 1 & & & & Istiqamah, Taqwa,Ihsan \\
\hline 18 & Hud (11:123) & 1 & & & 1 & & & & Tawakkul \\
\hline 19 & Yusuf (12:67) & 1 & & & & & 1 & & Tawakkul \\
\hline 20 & Ibrahim (14:23-26) & 1 & & & 1 & & & & Taqwa, Ihsan,Barakah \\
\hline 21 & Ibrahim (14:27) & 1 & & & 1 & & & & Istiqamah \\
\hline 22 & An-Nahl (16:97) & 1 & & & 1 & & & & Ihsan, Barakah \\
\hline 23 & Al- Isra' (17:12) & & & 1 & 1 & & & & Taqwa \\
\hline 24 & Taha $(20: 15)$ & I & & & 1 & & & & Barakah \\
\hline 25 & Al-Mu'minun (23:60) & 1 & & & 1 & & & & Ihsan, Taqwa \\
\hline 26 & Al-Mu'minun (23:62) & 1 & & & 1 & & & & Taqwa, Ihsan \\
\hline 27 & An-Nur (24:64) & 1 & & & 1 & & & & Taqwa \\
\hline 28 & Al-Furqan (25:62) & & & 1 & 1 & & & & Taqwa, Shukr \\
\hline 29 & Al-Furqan (25:63) & 1 & & & 1 & & & & Sabr \\
\hline
\end{tabular}




\begin{tabular}{|l|l|l|l|l|l|l|l|l|l|}
\hline 30 & Al-Furqan (25:67) & $/$ & & & $/$ & & & & Shukr \\
\hline 31 & An-Naml (27:86) & & & $/$ & $/$ & & & & Taqwa \\
\hline 32 & Al-Qasas (28:73) & $/$ & & $/$ & & & & & Shukr \\
\hline 33 & Al-Ankabut (29:58-60) & $/$ & & & $/$ & & & & Tawakkul, Ihsan \\
\hline 34 & Luqman (31:17) & $/$ & & & $/$ & & & & Taqwa, Sabr \\
\hline 35 & Fussilat (41:37) & & & $/$ & $/$ & & & & Taqwa \\
\hline 36 & Al-Ahqaf (46:3) & $/$ & & & $/$ & & & & Taqwa \\
\hline 37 & Muhammad (47:33) & $/$ & & & $/$ & & & & Taqwa \\
\hline 38 & Muhammad (47:36) & $/$ & & & $/$ & & & & Barakah, Taqwa \\
\hline 39 & Adh-Dhariyat(51:56-58) & $/$ & & & $/$ & & & & Taqwa \\
\hline 40 & Al-Jumuah (62:10) & $/$ & & & $/$ & & & & Taqwa, Ihsan \\
\hline 41 & At-Talaq (65:3) & $/$ & & & $/$ & & & $/$ & Tawakkul \\
\hline 42 & An-Naba' (78:9-11) & & & $/$ & $/$ & & & & Taqwa \\
\hline 43 & Al-Asr (103:1-3) & & & $/$ & $/$ & & & & Taqwa, Ihsan, Sabr \\
\hline
\end{tabular}

\subsection{Discussion}

\subsubsection{The Process of Islamic Value-based Productivity}

The main element in management is the process. Process is defined as a sequence of interrelated activities that will transform inputs into outputs to achieve the organization's objectives. Normally, the objective is the high level of productivity. Thus, this concept can also be applied in Islamic valuebased productivity, as shown in Figure 2.However, the process for Islamic value-based productivity has a different goal compared to conventional productivity. Typically, the values of the conventional productivity are measured by using tangible indicators such as skills and knowledge of workers. While in the Islamic perspective, the values of productivity are measured beyond the tangible indicators; and shows that it isholistic and comprehensive which will be discussed in this section.

\section{Process: Input $\rightarrow$ Output $\rightarrow$ Ultimate Goal}

Figure2. Process of Islamic value-based productivity

Based on the analysis conducted and shown in the previous section, the values have been extracted from the selected Quranic verses and classified according to indicators. The study has found that the process productivity starts with the input, which consists of three main indicators; faith, intention, and time. Based on these indicators, seven values serve to foster productivity that is, the so-called Islamic productivity. The seven values are ihsan, itqan, taqwa, shukr, istiqamah, sabr and tawakkul. From a conventional point of view, productivity is measured on the efficiency of input, such as labor and capital, to produce a certain level of output. However, Islamic value-based productivity is measured beyond these tangible indicators. The study has found that indicators that have been used for output are spiritual, social, intellectual, and material (Marsudi, et al., 2019). Therefore, the value in these indicators is the Barakah (Divine Blessing) from Allah SWT. Finally, the whole process of productivity that applies all these values will set an ultimate goal which is Mardhatillah, the pleasure of Allah SWT.

\subsubsection{The Relationship Between the Indicators and Values}

The indicators are the most important element in developing the values. Specifically, for example, the value of Ihsan (Excellence)is developed through these indicators.Firstly, the relationship of Ihsan and faith is the meaning of Ihsan itself is connected to faith. Ihsan refers to the acts of worship by a believer with the belief that Allah is present and watching the act of worship(Kadhim et al., 2017), which means it is closely related to faith, every act of action and worship should be done for the sake of Allah SWT alone. As mentioned in Surah An- Nisa' verse 125,the verse indicates the ultimate faith by fully submitting themselves for Allah, worshipping Him with sincerity of heart of Him alone.

"And who is better in faith than those who 'fully' submit themselves to Allah, do good, and follow the Way of Abraham, the upright? Allah chose Abraham as a close friend." (An-Nisa', 4:125)

For instance, in working, Islamic value-based productivity will appear when the workers work with a clear intention and have a firm faith that Allah is watching every action they do and accentuate the importance of time management in their daily tasks. 
Second, we shall highlight the relationship of the intention with the values. In Islam, the intention is very important in every action that the believers do. Every action of worship will start with an intention, with this intention; it will derive the motivation towards the outcome or goals. As mentioned in the Hadith,

\begin{abstract}
"I heard the Messenger of Allah ( say: "Actions are (judged) by motives (niyyah), so each man will have what he intended. Thus, he whose migration (hijrah) was to Allah and His Messenger, his migration is to Allah and His Messenger; but he whose migration was for some worldly thing he might gain, or for a wife he might marry, his migration is to that for which he migrated." (An-Nawawi, No. Hadith: 1)
\end{abstract}

This hadith indicates that every action is judged by motives or what we called intention (Niyyah). It also shows that every value applied in this study must start with good intention, and the outcome of productivity will also be excellent. If the opposites happen, it will lead to an unproductive and poor outcome.

Moreover, human beings have been appointed by God to carry out the responsibility and trust (amanah) of vicegerency (khilafah) or stewardship of God's earth.

\begin{abstract}
"Remember" when your Lord said to the angels, "I am going to place a successive "human "authority on earth." They asked 'Allah", "Will You place in it someone who will spread corruption there and shed blood while we glorify Your praises and proclaim Your holiness?" Allah responded, "I know what you do not know." (AlBaqarah, 2:30)
\end{abstract}

The vicegerent's (khilafah) roles are to execute the delegated powers, to fulfill the will or commandments, to manage or develop (imarah) life on earth according to the Divine guidance and code of life (shari'ah) or Divine Law, which is the prescribed normative way as revealed in His Scriptures. This means God intended the whole of human life on earth to be nothing more than a continuous and holistic manifestation of His vicegerents' worship of and service (ibadah) to the Creator-Sustainer (Abdul Rashid Moten, 2020).

"I have not created jinn and men, except that they should serve Me." (Al-Dhariyat, $51: 56)$

In this regard, Islamic spirituality requires humans' active involvement in all pursuits that contribute to the betterment, well-being (masslahah) and goodness of oneself, family, society, and humanity. With that being mentioned, all worldly activities in the economic, social, educational, technical, environmental, professional, or organizational aspects of life are considered as the worship of God if: i) the intention is to please God, ii) the goal, and iii) the approaches are ethical and in harmony with the Islamic law (Abdul Rashid Moten, 2020; Kamali et. al, 2008; Elias, 2017).

The final indicator is time, which represents the importance of time management in Islam. The relationship between the time and the values is that the whole element cannot be connected if time management is absent. For example, if the workers started their work with a firm faith and good intention applied the values, but lack in time management, it will impact the productivity outcome. The time is complementary to all these elements. In Islam, time is very crucial, as mentioned in the Quran, Surah Al- 'Asr verse 1-3. These verses indicate the importance of time in Islam and instruct all believers to fill their time with beneficial deeds and not wasting their time onun productive activities.

"By the 'passage of' time! Surely humanity is in 'grave" loss, except those who have faith, do good, and urge each other to the truth, and urge each other to perseverance." (Al-Asr, 103:1-2)

The value of Barakah was developed by the indicator of spiritual, social, intellectual, and material satisfaction according to Imam al-Ghazali. The satisfaction will be the indicator of the feeling of pleasure, the feeling of accomplishment and how satisfied they are with their work. These are related to Barakah.

The inseparability of Islamic spirituality from its manifestations in all kinds of socially, economically, ethically, or environmentally beneficial deeds is a unique feature of Islam. Hence, the pairing of faith and good deeds is emphasized in the Quran: 
"Do you not see how Allah compares a good word to a good tree? Its root is firm, and its branches reach the sky, 'always 'yielding its fruit in every season by the Will of its Lord. This is how Allah sets forth parables for the people, so perhaps they will be mindful". (Ibrahim, 14: 24-25)

Not only good deeds are highlighted in the Quran, but also the Prophet (SAW) was reported to have praised those who are beneficial to others, excellent in character, offer peace to the world and spend in charity even while poor. This means those who are productive and benefiting others are rewarded.

\subsubsection{The Ultimate Goal Islamic Value-based Productivity}

Typically, there is always focus on the goal or outcome from a set of inputs that have been applied in productivity. In Islamic Value-based Productivity, the ultimate goal ismardhatillah, reaching the pleasure of Allah SWT. This is because the concept of mardhatillah goal in material and spiritual development is the most superior and noble in Islam (Salleh, 2003). Also, according to Islam, working is an act of worship to achieve the pleasure of Allah SWT (Sharifah Hayaati, 2010). This has been mentioned in Quranic verse as follows.

"And patiently stick with those who call upon their Lord morning and evening, seeking His pleasure. ${ }^{1}$ Do not let your eyes look beyond them, desiring the luxuries of this worldly life. And do not obey those whose hearts We have made heedless of Our remembrance, who follow 'only' their desires and whose state is 'total' loss" (Al-Kahfi, 18:28)

This verse indicates the importance of encouragement in seeking Allah SWT's pleasure, focusing on the afterlife, the Hereafter (Akhirah), not only focusing on the worldly luxuries which refer to materials.

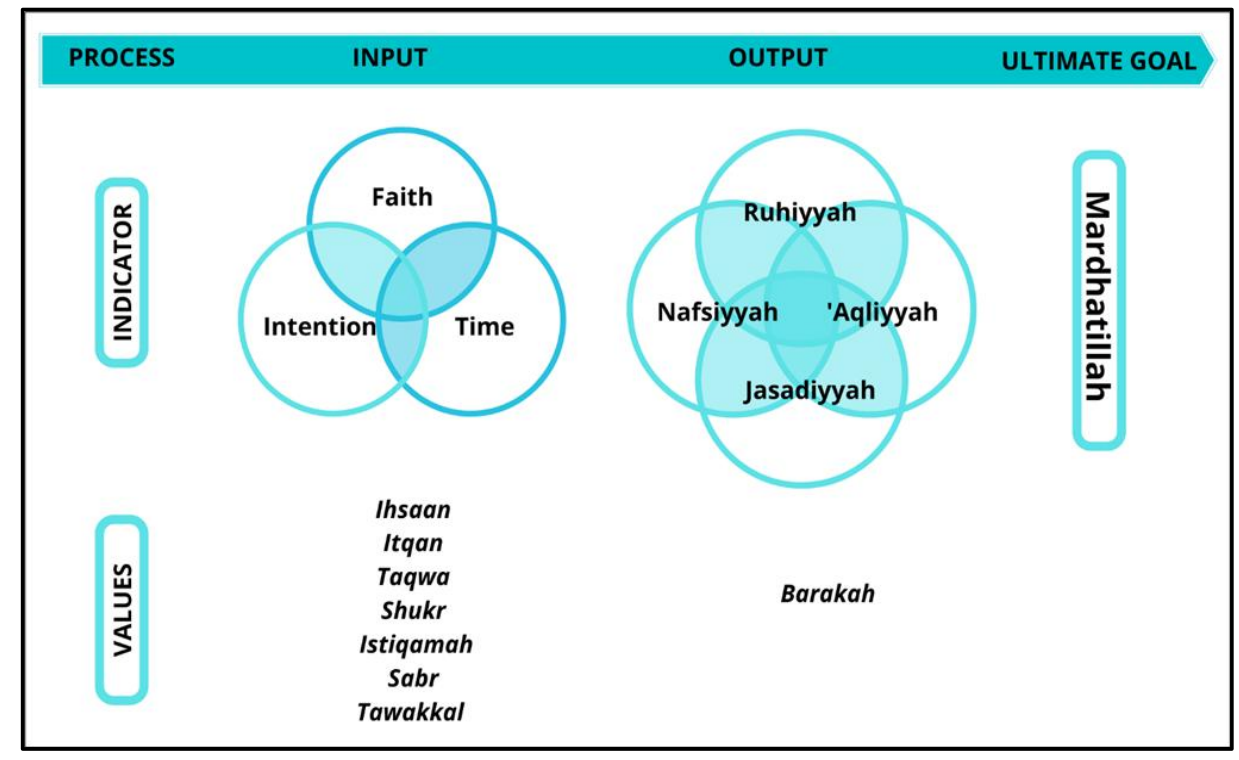

Figure3. Islamic Value-based Productivity Framework

It is believed that through a thorough understanding of the social and ethical values of Islam, a creative approach to meeting those challenges of sustainability that currently confront humanity can be developed. Al-Jouyussi (2012) proposed a framework for sustainable development based on four components of the worldview of Islam, namely good governance (' $a d l$ ), excellence (ihsan), social capital (arhma) and integrity without corruption (fasad). The four elements are linked to two domains, which are good life and construction of the universe. This framework is in line with the Islamic Value-based Productivity Framework.

\section{CONCLUSION}

Based on the working paper's overall discussion, 43 verses in the Quran related to Islamic productivity fulfilled the objectives. There are four indicators, and eight values extracted from the alQuran. Hence, Islamic value-based Productivity is effectively and comprehensively based on the existing Islamic framework. 


\section{ACKNOWLEDGEMENT}

This working paper is part of the research finding entitled "Developing a Measuring Tool for Islamic Value-based Productivity in Islamic Higher Education Institution", funded by the IIUM Flagship Research Initiative Grant Scheme (IRF), International Islamic University Malaysia, Gombak, Malaysia.

\section{REFERENCES}

[1] Abdul Rashid Moten. (2020). Spiritual and Sustainability Experiences of The International Islamic University Malaysia. Gombak: IIUM Press

[2] Ali, A. J., \& Weir, D. (2005). Islamic Perspectives on Management and Organization. Journal of Management, Spirituality \& Religion, 2(3), 410-415 https://doi.org/10.1080/14766080509518602.

[3] Elias, E. M., Othman, S.N., \& Yaacob, N.A. (2017). Relationship of spirituality leadership style and SMEs performance in halal supply Chain, International Journal of Supply Chain Management. 6(2), 166-176. ISSN 2050-7399.

[4] Gordon J, Zhou S, \&Gretton P. (2015). What is productivity and how is it measured. PC News, 17-19. Retrieved from https://www.pc.gov.au/news-media/pc-news/previous-editions/pc-news-may2015/productivity-and-how-measured.

[5] Hasmy, Z. A. (2019). KonsepProduktifitasKerjaDalam Islam. BALANCA: JurnalEkonomi Dan Bisnis Islam, 1(2).196-211. https://doi.org/10.35905/balanca.v1i2.1144.

[6] Hayati Ishak, A., Khadijah Ab Manan, S., Saidon, R., \& Huda Sahari, N. (2018). Proposing Islamic Values Implementation in Workplace: Analysis via Rasch Model. International Journal of Engineering \& Technology, 7(4.38),1345-1349. https://doi.org/10.14419/ijet.v7i4.38.27821

[7] Ishak, A. H., Osman, M. R., \& Din, G. (2015). Expert consensus on dimensions of islamic values in quality management practice: Analysis of fuzzy delphi method. Turkish Online Journal of Educational Technology, 2015, 273-280DOI: 10.14419/ijet.v7i4.38.27821.

[8] Kadhim, A. S., Ahmad, S., Owoyemi, M. Y., \& Ahmad, M. (2017). Islamic Ethics: The Attributes of AlIhsan in the Quran and Its Effects on Muslim Morality. International Journal of Business and Social Science, 8(11). 102-107. DOI: 10.30845/ijbss.

[9] Kamali, M. H., Khan, S., Al, S.-A. A., \& International Institute of Islamic Thought. (2008). MaqāșidalShariảh made simple. London: International Institute of Islamic Thought.

[10] Malaysia Productivity Report. (2019). In Malaysia Productivity Corporation (Vol. 26). Retrieved from http://www.mpc.gov.my/.

[11] Marsudi, Febriani, R., Sa'diyah, C., \&Pratika, Y. (2019). The Implementation of Islamic Values in Improving the Quality of Employee Performance in Workplace. KnE Social Sciences, 3(13).559-575. https://doi.org/10.18502/kss.v3i13.4231.

[12] Mohammed Faris. (2017). The Productive Muslim Where Faith Meets Productivity (Remona Aly, Ed.; Fourth). London: Awakening Publications.

[13] Muhammad Syukri Salleh. (2003). TujuhPrinsip Pembangunan Berteraskan Islam. Kuala Lumpur: Zebra Editions.

[14] O. Al Jayyousi, Rashed. (2012). Islam and Sustainable Development: New Worldviews. https://doi.org/10.4324/9781315589947

[15] Syverson, C. (2011). What determines productivity. Journal of Economic Literature, 49(2),326-65. https://doi.org/10.1257/jel.49.2.326

\section{AUTHORS' BIOGRAPHY}

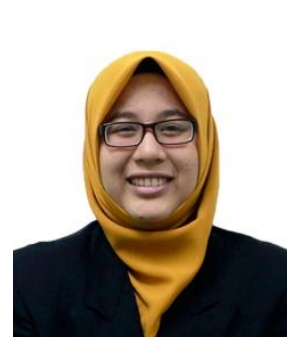

Nurul Ain Mohammad Rosli, is a Master's degree student in Halal Management studentat International Institute for Halal Research and Training (INHART), International Islamic University Malaysia. She graduated in bachelor'sdegree in Islamic Revealed Knowledge and Heritage (Fiqh and UsulFiqh) (Honours) at the same university. Currently, she works as Research Assistant for grant project"Developing a Measuring Tool for Islamic Valuebased Productivity in Islamic Higher Education Institution", funded by the IIUM Flagship Research Initiative Grant Scheme (IRF), International Islamic University Malaysia, Gombak, Malaysia. 


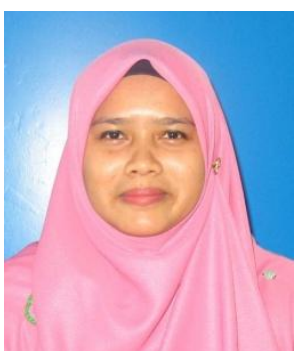

Dr.Norazilawati Md Dahlal, has joined the International Institute for Halal Research and Training (INHART), IIUM as an assistant professor since February 2019. She earned her doctorate in philosophy from the Universiti Sains Malaysia, Pulau Pinang in 2017. Her Ph.D thesis examined the concept of Halal Food Quality Management from the Islamic philosophy aspects. Dr. Nora started her interest in this field since she received her bachelor's degree in Food Technology in 2007. After four years involved in the food and management industrial sectors, she continued her master's degree in Islamic Development Management and continued with the doctoral level at the same university. The combination of the sciences and management studies has created her passion in the transdisciplinary approach in food quality management, especially in Halal Food Quality Management.

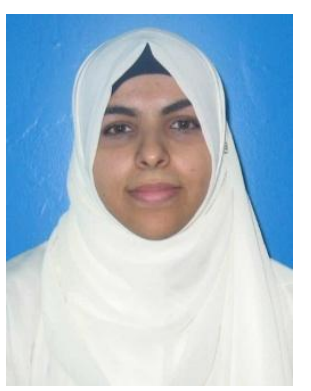

Amal A. M. Elgharbawy, is an Assistant Professor at the International Institute for Halal Research and Training (INHART). She obtained her $\mathrm{PhD}$ in Engineering from the International Islamic University Malaysia (IIUM) in 2018, and her Master's in Biotechnology Engineering in 2013. She obtained obtained her B.Sc. (Hons.) from King Abdul Aziz University, Saudi Arabia, and was awarded First Honor and Excellence Award. Dr. Amal started her research career as Research Associate (2017-2018) at University of Malaya and joined INHART as a research fellow (2018-2020). She has published several articles in national and international conferences, SCOPUS and ISI indexed journals and book chapters. She is currently an associate member of Nanoscience \& Nanotechnology Research Group (NanoRG). She is also Mendeley Advisor and a member of Malaysian Society of Bioinformatics and Computational Biology and the Society for Conservation Biology (Nov 2019- Nov 2020).

Citation: Nurul Ain Mohammad Rosli, et.al, "An Introduction of Islamic Value-Based Productivity Framework" International Journal of Managerial Studies and Research (IJMSR), vol 9, no. 4, 2021, pp. 118126. doi: https://doi.org/10.20431/2349-0349.0904010.

Copyright: (C) 2021 Authors. This is an open-access article distributed under the terms of the Creative Commons Attribution License, which permits unrestricted use, distribution, and reproduction in any medium, provided the original author and source are credited. 